\title{
Effect of different cooking methods on chemical composition, nutritional values, and sensory properties of Jack bean (Canavalia ensiformis) tempe
}

\author{
Purwandari, F.A., Annisa, E.D.N., Rachmawati, A.T., Puspitasari, D., "Wikandari, R., \\ Setyaningsih, W., Ningrum, A. and Sardjono \\ Department of Food and Agricultural Product Technology, Faculty of Agricultural Technology, Gadjah \\ Mada University, Jalan Flora 1, Bulaksumur, Caturtunggal, Depok, Sleman, Yogyakarta 55281, Indonesia
}

\begin{abstract}
Article history:
Received: 24 September 2020

Received in revised form: 27

October 2020

Accepted: 17 December 2020

Available Online: 20 June 2021
\end{abstract}

Keywords:

Jack bean,

Cooking methods,

Chemical composition,

Protein digestibility,

Sensory

DOI:

https://doi.org/10.26656/fr.2017.5(3).530

\begin{abstract}
Having high protein content, jack bean is a promising resource for making tempe, a traditional fermented food commonly consumed in Indonesia. The current research aimed to investigate the effect of different cooking methods (boiling, steaming, frying, and baking) on a chemical, nutritional, and sensory aspects of jack bean tempe. The results showed that the highest protein content and antioxidant activity of the processed tempe were obtained by steaming method with a value of $380.3 \mathrm{~g} / \mathrm{kg}$ and $57.8 \%$, respectively. The steaming process could maintain protein and mineral contents as well as the antioxidant activity. The boiled tempe had six time lower of phytic acid compared to that of control. The baking and frying process increased five to six-fold of the fat content, while reduced the protein content by $30 \%$. For the sensory evaluation, the baked tempe obtained the highest score. In conclusion, from a nutritional point of view, steaming is the best method for cooking jack bean tempe, while in term of sensory, baking is recommended.
\end{abstract}

\section{Introduction}

Indonesia is among the top five countries in Southeast Asia with a high rate of stunting (Lee, 2014), in which approximately one-third of Indonesian children suffer from stunting (National Institute of Health Research and Development, 2013). One risk factor associated with stunting is protein quality (Ghosh et al., 2012). In contrast, Indonesia is known as one of the megadiverse countries with enormous varieties of legumes as protein sources. However, only less than thirty varieties are consumed (Mead, 2017). Therefore, it is crucial to explore new potential plant-based protein sources to enhance food security since a high dependency on plant-based protein still relies on soybean.

Jack bean is a potential protein source due to its protein content and quality, affordability, as well as productivity. Jack bean flour contains $269 \mathrm{~g} / \mathrm{kg}$ protein (Betancur-Ancona et al., 2008). It has high productivity of up to 6 tons/ha (BPTP, 2014), while soybean's productivity is 1.6 tons/ha in 2015 (BPS, 2016). It has adequate essential amino acids except for methionine and cysteine, which are limited in most legumes. However, the usage of jack bean is limited by its antinutrient compounds such as concanavalin A, phytic acid, hydrogen cyanide, trypsin inhibitor, tannin, and phenols (Sumner and Howell, 1936; Doss et al., 2011; Widaningrum et al., 2015). Fermentation is known could reduce anti-nutrient compounds and increase protein digestibility in legumes; hence jack bean is commonly consumed in its fermented form namely tempe. Consumption of jack bean tempe is still restricted in Yogyakarta and Central Java Province and not as popular as tempe made from soybean.

Moreover, tempe is commonly consumed as a cooked meal. The cooking process could have a positive effect on food, such as improvement of the flavour, digestibility, and palatability of food and increase food safety from decaying microorganisms and inactivation of anti-nutrient factors. On the other hand, cooking can modify the biological, chemical, and physical properties of food. During the thermal process, modification can occur on texture, turgor pressure, odour, colour, and nutritional value. Among the changes, nutritional value and sensory are the significant factors that are considered by the consumers. The changes in nutritional value are affected by the concentration and bioavailability of bioactive components in foodstuff (Palermo et al., 2014). To the best of our knowledge, no literature research has been reported on the change of nutritional factors due to 
different cooking methods in jack bean tempe. In this article, we applied various dry- and wet-heat cooking methods i.e. boiled, steamed, fried, and roasted. We observed further the change in proximate value, antinutrient content, antioxidant activity, protein digestibility, and free amino acid profile. The data obtained from the study would provide beneficial information for consumers of jack bean foods.

\section{Materials and methods}

\subsection{Materials}

Jack bean (Canavalia ensiformis), inoculum Rhizopus oligosporus (Raprima), and palm oil were obtained from a local market in Yogyakarta, Indonesia. All the chemicals are analytical grade purchased from Sigma-Aldrich. For multi enzyme digestion, pepsin from porcine gastric mucosa P6887 (3200-4500 U/mg) and pancreatin from porcine pancreas P7545 (8xUSP) were used.

\subsection{Sample preparation}

Tempe was made by soaking the jack bean for $48 \mathrm{hrs}$ with bean to water ratio of $1: 2$ before peel removal. It was boiled for 30 mins and continued with a second soaking stage for $12 \mathrm{hrs}$. The next step is chopping followed by boiling. The cooked bean was then inoculated with tempe stater powder with a ratio of $1 \mathrm{~g}$ starter for $1 \mathrm{~kg}$ of the bean. It was incubated at room temperature for $68 \mathrm{hrs}$ in a plastic bag that contained approximately $190 \mathrm{~g}$ beans.

\subsection{Cooking method}

Jack bean was cooked after cutting into small pieces $(5.5 \times 4.5 \times 1.2 \mathrm{~cm})$. The optimum cooking method condition was determined by sensory evaluation (data not shown). The cooking of tempe included boiling, steaming, frying, and baking. The boiling was conducted at $100^{\circ} \mathrm{C}$ for 15 mins in a stainless-steel vessel with tempe to water ratio of $1: 3(\mathrm{w} / \mathrm{v})$. The steaming was performed at $102^{\circ} \mathrm{C}$ for $25 \mathrm{mins}$ in a stainless steel vessel. The frying was conducted at $162^{\circ} \mathrm{C}$ for 3 mins with a tempe and an oil ratio of $1: 3(\mathrm{w} / \mathrm{v})$. The baking was performed in a domestic oven (Kirin KBO-350RA, $35 \mathrm{~L}, 400$ watts) at $155^{\circ} \mathrm{C}$ for 20 mins. Raw and cooked samples were subjected to freeze-drying. The sample powder was kept at $4{ }^{\circ} \mathrm{C}$ in a sealed container before use.

\subsection{Proximate and anti-nutrient analysis}

Protein, fat, ash and moisture content were measured using the standard methods of analysis (AOAC, 1995). Phytic acid content was determined using a method described by Davies and Reid (1979) with modifications.
Samples powder of $1 \mathrm{~g}$ were extracted with $20 \mathrm{~mL}, 0.5$ $\mathrm{M} \mathrm{HNO}_{3}$, for 3-4 hrs with continuous shaking followed by filtering. Filtrate $(0.4 \mathrm{~mL})$ was then added to $1 \mathrm{~mL}$ distilled water and $1 \mathrm{~mL} \mathrm{FeCl}_{3}\left(0.2 \mathrm{mg} \mathrm{mL}^{-1}\right)$ followed by heating in boiled water for 20 mins. After cooling, 5 $\mathrm{mL}$ amyl alcohol and $0.1 \mathrm{~mL}$ ammonium thiocyanate $10 \%$ were added. It was then measured for the absorbance at $465 \mathrm{~nm}$ spectrophotometer (UV-1601 Shimadzu) after 15 mins incubation.

\subsection{DPPH radical scavenging activity}

The stable 2,2-diphenyl-1-picrylhydrazyl (DPPH) radical was used to measure the free radical scavenging capacity of samples as described by Alvarez-Jubete et al. (2010) with modifications. Samples of $0.5 \mathrm{~g}$ were extracted using $25 \mathrm{~mL}$ methanol with stirring for 3 mins. Mixtures were sonicated for $3 \mathrm{~min}$ before centrifugation at $2600 \times g$ for 5 mins. The clear solution $(0.5 \mathrm{~mL})$ was then added to $0.5 \mathrm{~mL}$ DPPH-methanolic solution $(0.05$ $\mathrm{mg} / \mathrm{mL}$ ) and mixed by vortex before incubation in the dark for 30 mins. The absorbance was then measured against methanol at $515 \mathrm{~nm}$ using a spectrophotometer (UV-1601 Shimadzu). The antioxidant activity was calculated as follow:

$$
\% \text { Antioxidant activity }=\left(\mathrm{A}_{\mathrm{o}}-\mathrm{A}_{\mathrm{f}}\right) / \mathrm{A}_{\mathrm{o}} \times 100
$$

Where $A_{o}$ and $A_{f}$ were absorbances of blank and sample, respectively.

\subsection{In vitro protein digestibility (IVPD)}

In vitro protein digestibility of jack bean was determined using a pepsin-pancreatin method with slight modifications by Almeida et al. (2015). A total of 250 mg of each sample and casein (for the reference) or 0.25 $\mathrm{mL}$ of deionized water (for the blank) was suspended in $15 \mathrm{~mL}$ of $0.1 \mathrm{M} \mathrm{HCl}$ containing $1.5 \mathrm{mg} / \mathrm{mL}$ pepsin, and incubated for $3 \mathrm{hrs}$ at $37^{\circ} \mathrm{C}$ in a waterbath. The pepsin hydrolysis was stopped with the addition of $7.5 \mathrm{~mL}$ of $0.5 \mathrm{M} \mathrm{NaOH}$ and followed by the pancreatic digestion with the addition of $10 \mathrm{~mL}$ of $0.2 \mathrm{M}$ phosphate buffer (pH 8.0) containing $10 \mathrm{mg}$ of pancreatin and addition of $1 \mathrm{~mL}$ of $0.005 \mathrm{M}$ sodium azide to prevent microbial growth. The mixture was incubated at $37^{\circ} \mathrm{C}$ overnight before the addition of $1 \mathrm{~mL}$ of $10 \mathrm{~g} / 100 \mathrm{~mL}$ of trichloroacetic acid (TCA). Samples were then centrifuged at $2600 \times g$ for 10 mins. Total protein content was estimated based on the nitrogen content using Kjeldahl from the supernatant phase (AOAC, 1995). The IVPD values were calculated according to the equation:

$$
\% \text { Digestibility }=\left(\mathrm{N}_{\mathrm{s}}-\mathrm{N}_{\mathrm{b}}\right) / \mathrm{N}_{\mathrm{s}} \times 100
$$

Where $\mathrm{N}_{\mathrm{s}}$ and $\mathrm{N}_{\mathrm{b}}$ represent the nitrogen content in the sample and the blank, respectively. 


\subsection{Sensory evaluation}

The sensory evaluation of jack bean tempe used in this study is descriptive profiling, which is conducted by thirty trained panellists. The sensory analysis was carried out in the Sensory Laboratory, Department of Food and Agriculture Product Technology, Universitas Gadjah Mada in Indonesia. Descriptive Profiling was used with four selected descriptors, including the degree of brownness for appearance, the beany flavour for aroma, the degree of umami for taste, and softness for texture. The descriptors had four intensity levels: 0 , none; faintly perceptible; 2 , moderate; 3 , strong; 4 , very strong. The test was performed individually by each panellist, and then the mean value was calculated.

\subsection{Statistical analysis}

Statistical analysis was performed for all data using One Way ANOVA IBM SPSS $20(\mathrm{p}<0.05)$, followed by Duncan.

\section{Results and discussion}

\subsection{Effect different cooking methods on proximate composition}

Jack bean seed is a potential local resource for making tempe as it contains $29.8 \mathrm{~g} / 100 \mathrm{~g}$ of protein, 50.8 $\mathrm{g} / 100 \mathrm{~g}$ of carbohydrate, $4.2 \mathrm{~g} / 100 \mathrm{~g}$ of lipid, and 4.48 $\mathrm{g} / 100 \mathrm{~g}$ of ash (Doss et al., 2011). This composition is comparable with soybean as the major raw material currently for tempe productions. Soybean contains 37.10 - $41.79 \%$ of protein (Astawan et al., 2013). The proximate composition of jack bean tempe showed that it comprises $37.5 \mathrm{~g} / 100 \mathrm{~g}$ protein, $56.5 \mathrm{~g} / 100 \mathrm{~g}$ carbohydrates, $4.95 \mathrm{~g} / 100 \mathrm{~g}$ of fat, and $1.01 \mathrm{~g} / 100 \mathrm{~g}$ ash. The recommended dietary allowance for protein is $57 \mathrm{~g}$, and this can be fulfilled by eating $150 \mathrm{~g}$ of jack bean tempe or six small pieces of tempe.

The effect of different cooking methods on the proximate composition of jack bean tempe is presented in Table 1. In general, the cooking process significantly affected the proximate composition of jack bean tempe. The results showed that the protein content of the cooked jack bean tempe decreased significantly in boiled, baked, and fried tempe. During fermentation complex protein is degraded into peptides and amino acids (Pranoto et al.,
2013) which generally more soluble in water resulted in the decrease of protein content on boiled tempe. Fermentation could alter the amino acids into ammonia and other volatile compound (Pranoto et al., 2013) that is more easily be evaporated during a heat treatment process. However, we believe that a significant decrease in baked and fried tempe is likely due to the relative proportion of protein to fat content. As showed the fat content increased in fried and baked tempe, compared with the raw tempe, due to the use of oil during the process. Before baking, the raw tempe was dipped in palm oil to avoid burning. Nevertheless, the usage of water during cooking has less affected the proximate composition of jack bean tempe.

\subsection{Effect cooking method on nutritional value}

Heating and soaking in water during the cooking process might degrade heat-sensitive compounds and dissolve the water-soluble compound. Hence, the cooking method might affect the nutritional value. The current research investigated the effect of cooking methods on antioxidant activity, anti-nutrient compound, and protein digestibility. Figure 1 shows that, in general, the cooking method applied in this study significantly decreased the antioxidant activity when compared with the control. Antioxidant activity was reduced in the range of $6-22 \%$. It could be because a significant decrease of phenol, tannin, and flavonoid compounds may occur resulting in decreased antioxidant activity (Sasipriya and Siddhuraju, 2012). Tempe is abundant in flavonoid compounds (Athaillah et al., 2019), and flavonoid has several positive impacts on our health. Flavonoids can modulate many biological events in cancer, such as apoptosis, vascularization, cell differentiation, and cell proliferation (Batra and Sharma, 2013). Nevertheless, steaming methods are more able to retain antioxidant activity compared to boiling, frying, and baking methods. One explanation could be that flavonoids are highly unstable compounds; hence, they are easily degraded and released into the cooking medium at high temperatures (Saikia and Mahanta, 2013).

Raw jack bean contains $0.87 \mathrm{~g} / 100 \mathrm{~g}$ phytate (Diniyah and Windrati, 2015), whereas soybean is 1.39 g/100 g (Almasyhuri et al., 1990). Phytate is soluble in

Table 1. Proximate analysis of raw- and cooked- jack bean tempe

\begin{tabular}{lccccc}
\hline \multicolumn{1}{c}{ Tempe } & Protein $(\mathrm{g} / \mathrm{kg})$ & Lipid $(\mathrm{g} / \mathrm{kg})$ & Ash $(\mathrm{g} / \mathrm{kg})$ & Carbohydrate $(\mathrm{g} / \mathrm{kg})$ & Moisture $(\mathrm{g} / \mathrm{kg})$ \\
\hline Raw & $374.8 \pm 9.7^{\mathrm{a}}$ & $49.5 \pm 10.1^{\mathrm{a}}$ & $10.1 \pm 0.3^{\mathrm{a}}$ & $565.1 \pm 7.4^{\mathrm{ab}}$ & $45.3 \pm 4.1^{\mathrm{a}}$ \\
Steamed & $380.3 \pm 7.3^{\mathrm{a}}$ & $68.1 \pm 4.7^{\mathrm{a}}$ & $11.2 \pm 0.2^{\mathrm{b}}$ & $587.2 \pm 4.2^{\mathrm{a}}$ & $59.0 \pm 3.5^{\mathrm{b}}$ \\
Boiled & $329.1 \pm 5.9^{\mathrm{b}}$ & $72.2 \pm 1.8^{\mathrm{a}}$ & $10.7 \pm 0.4^{\mathrm{b}}$ & $539.6 \pm 7.0^{\mathrm{b}}$ & $57.0 \pm 2.2^{\mathrm{b}}$ \\
Fried & $260.5 \pm 6.8^{\mathrm{c}}$ & $315.9 \pm 9.5^{\mathrm{b}}$ & $7.7 \pm 0.2^{\mathrm{c}}$ & $415.6 \pm 3.6^{\mathrm{c}}$ & $46.0 \pm 5.7^{\mathrm{a}}$ \\
Baked & $262.3 \pm 7.7^{\mathrm{c}}$ & $292.9 \pm 30.7^{\mathrm{b}}$ & $7.7 \pm 0.2^{\mathrm{c}}$ & $436.6 \pm 31.6^{\mathrm{c}}$ & $47.8 \pm 3.1^{\mathrm{a}}$ \\
\hline
\end{tabular}


water and sensitive to heat; therefore, the concentration might decrease during tempe production and cooking of jack bean tempe. The phytate content of jack bean tempe was $0.019 \mathrm{~g} / \mathrm{kg}$. The phytate content of all cooked jack bean tempe ranged from 0.003 to $0.09 \mathrm{~g} / \mathrm{kg}$ (Figure 2). It is only a boiling process that further decreased the phytate content, which could be due to further dissolution of phytate. The phytate content for both raw and all cooked tempe was lower than the maximum acceptable concentrations in the food. Hence, jack bean tempe is safe for consumption.

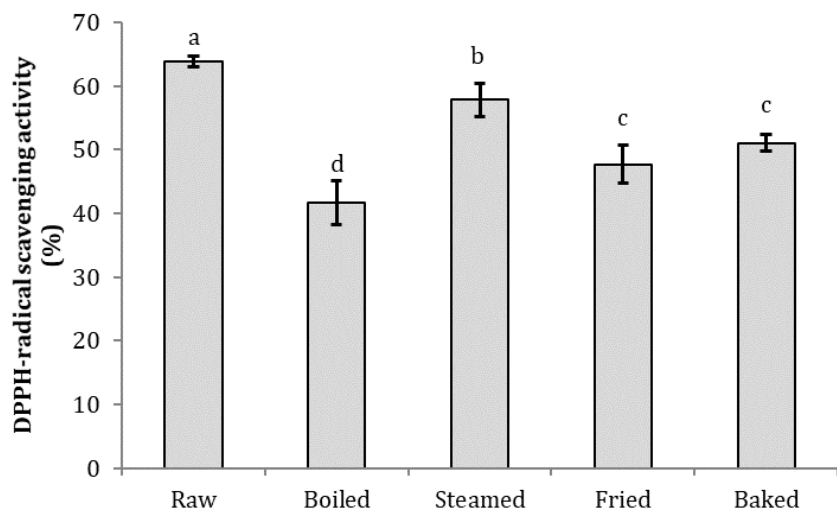

Figure 1. DPPH radical scavenging activity in raw- and cooked- jack bean tempe using different cooking methods

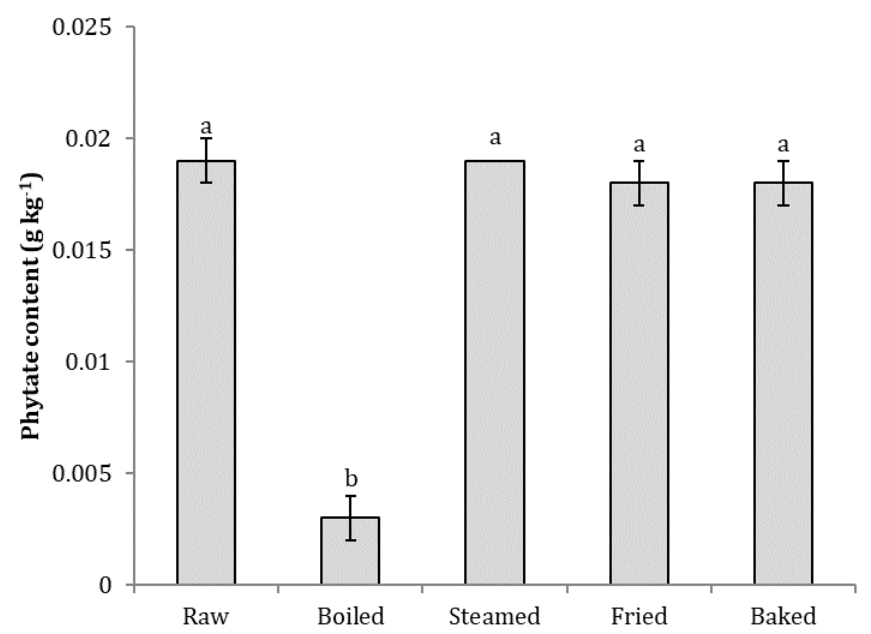

Figure 2. Phytate content in raw- and cooked- jack bean tempe using different cooking methods

The in vitro protein digestibility is a crucial biochemical parameter to assess the nutritional quality of the tempe. The higher the protein digestibility, the better the protein quality. To evaluate the protein digestibility, casein was used as a standard for comparison. The protein digestibility obtained in this study was $96.48 \%$, which was similar to another study (96.08\%) reported by Tavano et al. (2008). As can be seen in Figure 3, the protein digestibility of raw jack bean was $91.25 \pm 2.46 \%$, which corresponding to $94.58 \%$ compared to the standard. This result showed that jack bean tempe has a good protein quality as the body easily absorbed it. Cooking methods could maintain the protein digestibility of jack bean tempe, except for the baking technique, which resulted in a slight decrease by $4.61 \%$ of protein digestibility. This could be explained by several chemical reactions during the baking process such as Maillard, oxidation of amino acids, racemization of active optical amino acids, and formation of protein complexes. All of these reaction products can lower protein digestion (Gilani et al., 2005).

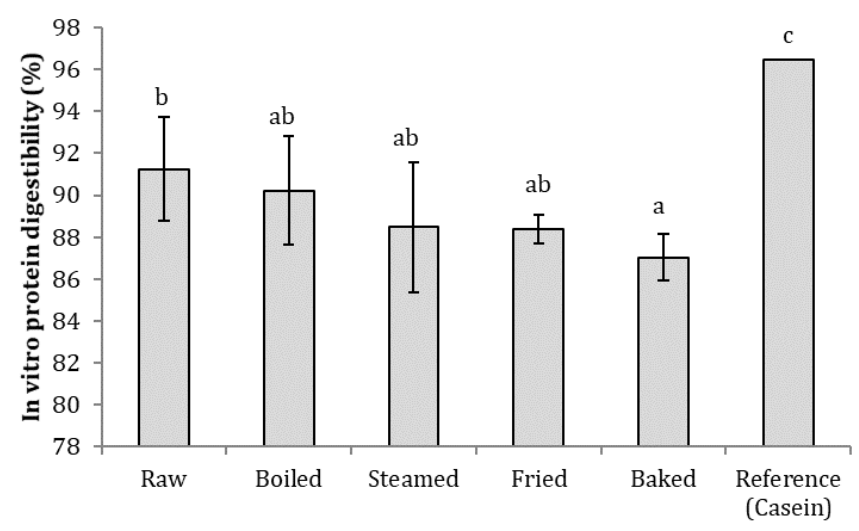

Figure 3. In vitro protein digestibility in raw- and cookedjack bean tempe using different cooking method

\subsection{Effect cooking method on the sensory profile}

Appearance, aroma, texture, and taste are important parameters that affect consumer acceptance. For soybean tempe, consumers prefer a cooked soybean tempe, which has golden brown colour, umami taste, less bitter, less beany flavour (Laksono et al., 2019). Hence, the effects of different cooking methods on the sensory of cooked jack bean tempe were evaluated. One critical attribute that affects the appearance of the tempe was the degree of brownness. The higher the degree of brownness, the higher the score was obtained. The result showed that frying had a higher degree of brownness, followed by baking, boiling, and steaming (Figure 4). During a heat treatment process, Maillard reaction may occur between amino acids and reducing sugars which generate different flavours and brown colour (Tamanna and Mahmood, 2015), the reaction is typically at 100 to $250^{\circ}$ C (Bastos et al., 2012). However, incorporating water could inhibit the Maillard reaction since the water was able to dilute the reagents for the Maillard reaction (Pastoriza et al., 2018), therefore the melanoidins that responsible for the brown colour formation could not be formed. The Maillard reaction was found in frying and baking as shown as brown colour perceived by the panellist.

The descriptive analysis for the flavour showed that beany flavour was detected in boiled and steamed while fried and baked showed less beany flavour. Beany flavour is formed by a mixture of various volatile compounds, including methyl-1-butanol, hexanal, 2,4decadienal, dimethyl disulfide (Boatright et al., 1999; Blagden and Gilliland, 2005; Jeleń et al., 2013). Cooking 
at a temperature above $80^{\circ} \mathrm{C}$ significantly decreased the beany flavours (Yuan and Chang, 2007). Since baking and frying employ higher temperatures, hence the reduction of beany flavour was higher than that of boiling and steaming.

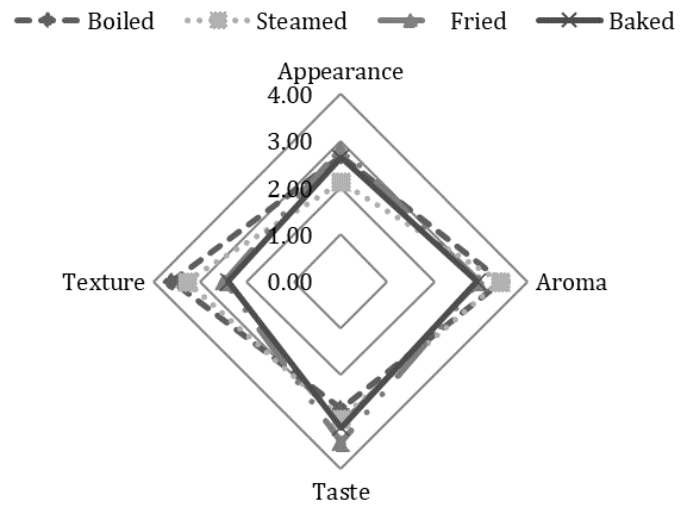

Figure 4. Spider-web chart representing mean scores of descriptive profiling of jack bean tempe. Sensory evaluation was performed by a sensory panel $(\mathrm{n}=30)$. Number $(0-3)$ represents the intensity level: $0=$ none; $1=$ faintly perceptible; $2=$ moderate; $3=$ strong; and $4=$ very strong

The taste of the tempe is correlated to the degree of umami. The panellist described that umami taste could be detected in fried and baked tempe, respectively, while boiled and steamed gave plain taste. This could be explained that oil can dissolve umami flavour compounds, thus resulted in more umami taste. Another reason could be the Maillard reaction that occurs during baking and frying. Maillard reaction significantly contributes to flavour, aroma, colour, and texture formation (Ames, 1990; Yu and Zhang, 2010).

The results of a descriptive test for texture showed that tempe with a wet cooking process such as boiling and steaming resulted in the softer texture of tempe compared to dry cooking (baking and frying). On the other hand, dry cooking resulted in harder texture, which is due to the loss of surface moisture leading to dehydration of crusts (Sobukola et al., 2013).

\section{Conclusion}

The cooking process changes the chemical composition, nutritional value, and flavour substance. It is necessary to understand the science of cooking methods; hence we can select and implement the appropriate cooking methods to attain our goal. In this study, high protein content and digestibility resulted in the steam process. However, if we concern about flavour and hedonic, we could choose the baking process compared to others.

\section{Conflict of interest}

The authors declare no conflict of interest.

\section{Acknowledgment}

The research was supported by the Ministry of Research and Technology of Indonesia through the grant of PDUPT with the contract number of 2847/ UN1.DITLIT/DIT-LIT/ PT/2020.

\section{References}

Almasyhuri, Yuniati, H. and Slamet, D.S. (1990). Kandungan asam fitat dan tanin dalam kacangkacangan yang dibuat tempe. Penelitian Gizi dan Makanan, 3(13), 65-72.

Almeida, C.C., Monteiro, M.L.G., Costa-Lima, B.R.C.da, Alvares, T.S. and Conte-Junior, C.A. (2015). In vitro digestibility of commercial whey protein supplements. LWT - Food Science and Technology, 61(1), 7-11. https://doi.org/10.1016/ j.lwt.2014.11.038

Alvarez-Jubete, L., Wijngaard, H., Arendt, E.K. and Gallagher, E. (2010). Polyphenol composition and in vitro antioxidant activity of amaranth, quinoa buckwheat and wheat as affected by sprouting and baking. Food Chemistry, 119(2), 770-778. https:// doi.org/10.1016/j.foodchem.2009.07.032

Ames, J.M. (1990). Control of the Maillard reaction in food systems. Trends in Food Science and Technology, 1, 150-154. https:// doi.org/10.1016/0924-2244(90)90113-D

AOAC. (1995). Official Methods of Analysis of AOAC International (sixteenth). Maryland: Association of Official Analytical Chemist.

Astawan, M., Wresdiyatib, T., Widowatic, S., Bintarid, S.H. and Ichsani, N. (2013). Karakteristik fisikokimia dan sifat fungsional tempe yang dihasilkan dari berbagai varietas kedelai. PANGAN, 22(3), 241-251. [In Bahasa Indonesia].

Athaillah, Z.A., Muzdalifah, D., Lestari, A., Fitria, A., Udin, L.Z., Artanti, N. and Lioe, H.N. (2019). Phenolic compound profile and functionality of aqueous overripe tempe extracts. Current Research in Nutrition and Food Science, 7(2), 382-392. https://doi.org/10.12944/CRNFSJ.7.2.08

Bastos, D.M., Érica, M., Séfora, Siguemoto, E., and Sefora, M. (2012). Maillard Reaction Products in Processed Food: Pros and Cons. In Valdez, B. (Eds). Food Industrial Processes Methods and Equipment, p. 281-300. InTech Open E-Book.

Batra, P. and Sharma, A.K. (2013). Anti-cancer potential of flavonoids: recent trends and future perspectives. 3 Biotech, 3(6), 439-459. https://doi.org/10.1007/ s13205-013-0117-5

Betancur-Ancona, D., Gallegos-Tintoré, S., DelgadoHerrera, A., Pérez-Flores, V., Castellanos Ruelas, A. 
and Chel-Guerrero, L. (2008). Some physicochemical and antinutritional properties of raw flours and protein isolates from Mucuna pruriens (velvet bean) and Canavalia ensiformis (jack bean). International Journal of Food Science and Technology, 43(5), 816-823. https:// doi.org/10.1111/j.1365-2621.2007.01521.x

Blagden, T.D. and Gilliland, S.E. (2005). Reduction of levels of volatile components associated with the beany flavor in soymilk by Lactobacilli and Streptococci. Journal of Food Science, 70(3), 2-5. https://doi.org/10.1111/j.1365-2621.2005.tb07148.x

Boatright, W.L., Lei, Q., Contributing, C. and Odor, B. (1999). Compounds contributing to the beany odor of aqueous solutions of soy protein isolates. Journal of Food Science, 64(4), 667-670. https:// doi.org/10.1111/j.1365-2621.1999.tb15107.x

BPS. (2016). Produktivitas Kedelai Menurut Provinsi (kuintal/ha), 1993-2015. Retrieved on January 15, 2020 from https://www.bps.go.id/ dynamictable/2015/09/09/872/produktivitas-kedelaimenurut-provinsi-kuintal-ha-1993-2015.html [In Bahasa Indonesia].

BPTP. (2014). Expedition 9: Coalition with Jack Bean, Substitution Soybean Requirement. Institute for Agricultural Technology. Indonesia: BPTP.

Davies, N.T. and Reid, H. (1979). An evaluation of the phytate, zinc, copper, iron and manganese contents of, and zn availability from, soya-based texturedvegetable-protein meat-substitutes or meatextenders. The British Journal of Nutrition, 41(3), 579-589. https://doi.org/10.1079/BJN19790073

Diniyah, N. and Windrati, W.S. (2015). Perubahan kandungan asam fitat dan asam sianida $(\mathrm{HCN})$ pada pre-proses koro-koroan, presented at Prosiding Annual Scientific Meeting POKJA Nutrigenomik: Seminar Nasional Peran Antioksidan Dalam Penanganan Penyakit Degeneraif Dengan Pendekatan Nutrigenomik, 2015. Yogyakarta: Gadjah Mada University. [In Bahasa Indonesia].

Doss, A., Pugalenthi, M., Vadivel, V.G., Subhashini, G. and Anitha Subash, R. (2011). Effects of processing technique on the nutritional composition and antinutrients content of under-utilized food legume Canavalia ensiformis L.DC. International Food Research Journal, 18(3), 965-970.

Ghosh, S., Suri, D. and Uauy, R. (2012). Assessment of protein adequacy in developing countries: quality matters. British Journal of Nutrition, 108(S2), S77S87. https://doi.org/10.1017/S0007114512002577

Gilani, G.M., Cockell, K.A. and Sepehr, E. (2005). Effects of antinutritional factors on protein digestibility and amino acid availability in foods. Journal of AOAC International, 88(2), 967-987. https://doi.org/10.1093/jaoac/88.3.967

Jeleń, H., Majcher, M., Ginja, A. and Kuligowski, M. (2013). Determination of compounds responsible for tempeh aroma. Food Chemistry, 141(1), 459-465. https://doi.org/10.1016/j.foodchem.2013.03.047

Laksono, A.S., Marniza and Rosalina, Y. (2019). Karakteristik mutu tempe kedelai lokal varietas Anjasmoro dengan variasi lama perebusan dan penggunaan jenis pengemas. Jurnal Agroindustri, 9 (1), $\quad$ 8-18. https://doi.org/10.31186/ j.agroindustri.9.1.8-18 [In Bahasa Indonesia].

Lee, D.E.R. (2014). Children's Protein Consumption in Southeast Asia: Consideration of Quality as well as Quantity of Children's Protein Consumption in Southeast Asia. Retrieved on January 10, 2020 from http://repository.upenn.edu/ wharton_research_scholars/115

Mead, D. (2017). A Guide to Some Edible Legumes of Indonesia, Issue 29. Retrieved on January 8, 2020 from http://sulang.org/sites/default/files/ sulanglextopics029-v2.pdf

National Institute of Health Research and Development. (2013). Pokok-pokok Hasil Riskesdas Indonesia 2013. Retrieved on September 22, 2020 from http:// kesga.kemkes.go.id/images/pedoman/Data Riskesdas 2013.pdf. [In Bahasa Indonesia].

Palermo, M., Pellegrini, N. and Fogliano, V. (2014). The effect of cooking on the phytochemical content of vegetables. Journal of the Science of Food and Agriculture, 94(6), 1057-1070. https:// doi.org/10.1002/jsfa.6478

Pastoriza, S., Quesada, J. and Rufián-Henares, J.A. (2018). Lactose and Oligosaccharides: Maillard Reaction. Reference Module in Food Science. Elsevier Reference Collection E-Book. https:// doi.org/10.1016/B978-0-08-100596-5.22552-3

Pranoto, Y., Anggrahini, S. and Effendi, Z. (2013). Effect of natural and Lactobacillus plantarum fermentation on in-vitro protein and starch digestibilities of sorghum flour. Food Bioscience, 2, 46-52. https://doi.org/10.1016/j.fbio.2013.04.001

Saikia, S. and Mahanta, C.L. (2013). Effect of steaming, boiling and microwave cooking on the total phenolics, flavonoids and antioxidant properties of different vegetables of Assam, India. International Journal of Food and Nutritional Science, 2(3), 4753.

Sasipriya, G. and Siddhuraju, P. (2012). Effect of different processing methods on antioxidant activity of underutilized legumes, Entada scandens seed 
kernel and Canavalia gladiata seeds. Food and Chemical Toxicology, 50(8), 2864-2872. https:// doi.org/10.1016/j.fct.2012.05.048

Sobukola, O.P., Dueik, V. and Bouchon, P. (2013). Understanding the effect of vacuum level in structure development and oil absorption in vacuum-fried wheat starch and gluten-based snacks. Food Bioprocess Technology, 6, 2010-2017. https:// doi.org/10.1007/s11947-012-0899-1

Sumner, J.B. and Howell, S.F. (1936). Identification of the hemagglutinin of the jack bean with concanavalin A. Journal of Bacteriology, 32(2), 227 -237. https://doi.org/10.1128/JB.32.2.227-237.1936

Tamanna, N. and Mahmood, N. (2015). Food Processing and Maillard Reaction Products: Effect in Human Health and Nutrition. International Journal of Food Science, 2015, 526762. https:// doi.org/10.1155/2015/526762

Tavano, O.L., Silva Junior, S.I., Demonte, A. and Neves, V.A. (2008). Nutritional responses of rats diets based on chickpea (Cicer arietinum L.) seed meal or its protein fractions. Journal of Agricultural and Food Chemistry, 56(22), 11006-11010. https:// doi.org/10.1021/jf8010799

Widaningrum, Sukasih, E. and Purwani, E.Y. (2015). Introductory study on processing of fermented jack bean (Canavalia ensiformis). Jurnal Penelitian Pascapanen Pertanian, 12(3), 129-136. https:// doi.org/10.21082/jpasca.v12n3.2015.129-136

$\mathrm{Yu}, \mathrm{A}$. and Zhang, A. (2010). The effect of $\mathrm{pH}$ on the formation of aroma compounds produced by heating a model system containing $\mathrm{L}$-ascorbic acid with L threonine/L -serine. Food Chemistry, 119(1), 214 219. https://doi.org/10.1016/j.foodchem.2009.06.026

Yuan, S.H. and Chang, S.K.C. (2007). Selected odor compounds in cooked soymilk as affected by soybean materials and direct steam injection. Journal of Food Science, 72(7), S481-S486. https:// doi.org/10.1111/j.1750-3841.2007.00461.x 